\title{
Game Analysis of Cooperation between Start-Up and Venture Investor
}

\section{Qunying Chen}

School of Management, Jinan University, Guangzhou, China

Email:752706602@qq.com

How to cite this paper: Chen, Q. Y. (2016). Game Analysis of Cooperation between StartUp and Venture Investor. Journal of Financial Risk Management, 5, 113-121. http://dx.doi.org/10.4236/jfrm.2016.53013

Received: July 22, 2016

Accepted: September 2, 2016

Published: September 5, 2016

Copyright (@) 2016 by author and Scientific Research Publishing Inc. This work is licensed under the Creative Commons Attribution International License (CC BY 4.0).

http://creativecommons.org/licenses/by/4.0/

\begin{abstract}
This article divides the cooperation style between start-ups and venture investors into non-property cooperation and property cooperation. On the basis, it sets up a dynamic game model of complete information to figure out the corresponding Nash equilibrium. And the game analysis results indicate that during the cooperative game process of start-up and venture investor, the higher extra input the venture investor needs to provide, the more likely the both sides are to choose non-property cooperation; the higher profits the success of the venture project may bring, the more likely the entrepreneurial firm is to choose property cooperation.
\end{abstract}

\section{Keywords}

Start-Up, Venture Investor, Cooperative Game, Dynamic Game Model of Complete Information

\section{Introduction}

As the Prime Minister of China, Li Keqiang, came up with in the government work report in 2015 that: "Mass entrepreneurship and innovation can not only create more jobs and increase personal incomes, but also improve upwards social mobility and social equity and justice". Also along with the rapid development of internet technology and economy, the new politic and market environments have spawned a large number of start-ups. It was said that since 2015, nearly 10,000 start-ups have been added every day in China. Meanwhile, start-ups will go through 4 phases including seed, start-up, growth and maturity (Huang \& Wang, 1998). At the early stage of starting a new business, enterprises need a large amount of money to move on the R\&D activities. Startups may apply for loan from banks or other financial institutions, in which the loans' standards are too high for start-ups to live up to. Thus, they are inclined to search for 
venture capital investment, as long as the business plan can appeal to the investor to invest this project.

Venture capital is a kind of investment behavior through investing capital into small and medium-sized unlisted start-ups, especially high-tech enterprises, in order to obtain high return by exiting the investment when the companies achieve IPO mergers and acquisitions or other ways of equity transfer (Xiao, Tan, \& Yuan, 2008). During the process, start-ups can receive the necessary fund to march on and the venture investor can reap high profits after finishing the project. The cooperation between start-ups and venture capital investor is a win-win behavior, thus becoming an overwhelming trend. However, both of them face unprecedented uncertainty and risk control in the cooperation process. For instance, entrepreneurs may take actions against the will of venture investors to achieve his own private benefits, which is called agency risk. And information that decision making needs during the cooperation is often unpredictable and unclear. Besides, the risks from the fierce market and complex reality add much uncertainty to both of them.

In order to lower the uncertainty and risk, lots of researches have been conducted to study the cooperation of start-up and capital investor to offer them appropriate strategies, eventually the issue is becoming a hot topic. We are faced with issues that how to help start-ups and capital investors to make wise and suitable decisions. Besides, well begun is half done, the selection and negotiation stage is very pivotal for the cooperation, which will influence the smooth advance of later stages. Based on this, this paper will focus on the game process in their selection and negotiation stage by the method of game theory and seek equilibrium strategy for gaming parties.

\section{Literature Review}

In recent years, many scholars have studied the relationships between start-up and venture capital firms from different angles. Some papers are based on venture capital investment at various stages according to enterprises' different growth stages, thus analyzing the cooperative game at three stages, which generally include initial investment stage, continued stage and withdrawal stage (Tu, 2005; Li, 2012; Jiang, 2014). Tu (2005) finds that cooperation is always the best choice for start-up and venture investor by setting an incomplete information game analysis model. On the basis, Li (2012) introduces backward induction method to analyze the game deeply, in order to highlight the different characteristics of each stage. Jiang (2014) establishes 3 different game models under the background of asymmetric information and finds that entrepreneurs' private income is an important factor to the cooperation effect. Additionally, some scholars use reputation systems and evolutionary game theory to study the relationship of start-up and venture capital provider which mainly focuses on adverse selection problems arising from asymmetric information (Ma \& Yuan, 2010). Finally they suggest that both sides should solve the adverse selection problems through the signal transmission mechanism, reputation mechanism and contract design. Though they have studied the cooperation process based on game theory thoroughly, the findings turn out to be broad 
and remain at the theoretical level, which are difficult for investors and start-ups to put into reality to achieve high performance. Therefore, this paper is going to study the cooperation relationship from a more pragmatic perspective.

Also, there are some studies focus on more detailed and specific issues about start-up and venture investor, such as the style and time of investors' exit and the capital investors' influence on start-ups etc. Wu et al. (2011) develop a model on exit decision to maximize profit of venture investors investing in the depth of product innovation. The results show that when the new product is sufficiently innovative, going public can be more profitable than a trade sale (selling the venture to the existing company). Mai et al. (2012) and Cai et al. (2015) study the impact of venture capital on innovative activity of venture enterprises empirically. They both find that venture capital is helpful to increase the entrepreneurial firms' innovation investment. From these researches, we can know that the style of investor's exit style will influence the performance and venture capital is good for the start-ups. However, they did not tell us what kinds of exit style are good for both sides and how venture capital influences the start-up.

As for the exit issue, Kaplan \& Stromberg (2001) think that the allocation of cash flow and control right should be settled clearly when start-ups and venture investors enter into the stage of making a contract, to ensure the effective operation of the enterprise. In addition, the cooperation model of start-ups and venture investor can be divided into two types. One is conducting control and incentives based on the contract and the financial mechanism without offering other services; another is offering value-added service based on the industry experience and business expertise (Dong, Zhai, \& Wang, 2014). In general, value-added services include assisting in developing strategic plans, helping enterprises to establish social resources network and to contact potential customers, acting as financing consultants to assist in constructing enterprises' internal incentive system etc. In the first model, the venture investors exit as equity investors with financial mechanism and we name the model non-property cooperation. In the second model, venture investor is a sustainable partner of the start-up, which has a very close tie with the start-up, so we name it property cooperation (Luo \& Tang, 2001). Thus, this paper is going to introduce the non-property and property cooperation at the selection and negotiation stages which can determine the allocation of profits and right of control apparently to enhance the efficiency of the cooperation. It is beneficial for both sides to decide the exit style at initial cooperation phrase.

In conclusion, this paper is setting up a complete information dynamic game model by introducing the non-property and property cooperation, to analyze the game of startup and investor at selection and negotiation stage, from which we can have a better understanding of how start-up and investor cooperate appropriately for their both interests from a new perspective, which has important theoretical and realistic significance.

\section{Start-Up-Venture Investor Cooperation Game}

\subsection{Description of the Game}

In the game course, start-ups have 3 choices in strategies, one of which is doing their 
own business, the second is non-property cooperation mode, and the third is property cooperation mode. Property cooperation is a closed cooperation between start-ups and venture investors. And as a partner of the start-up, venture investor will provide venture capital, management experience and other value-added services for start-up. Both sides rely on each other and share the entrepreneurial risks. In property cooperation style, the venture investor's purpose is to help the start-up to have a better development and achieve some personal values, eventually to share the profits and reputation together.

Non-property mode refers to a relatively loose style of cooperation. Relationship between both sides is contract alliances, in which venture investors only offer venture capital to start-ups and influence start-ups by contractual obligation. In non-property cooperation style, the venture investor is aimed to sell the item to other companies or transfer its equity after its success, eventually to reap high investment return.

This paper is about to establish a complete information dynamic game model of start-up and venture investor cooperation and address the following questions:

1) Under what conditions venture investor will choose to cooperate with start-ups?

2) If the venture investor chooses to collaborate with the start-up, when would venture investor take the non-property cooperation mode and when would he take the cooperation mode of property?

3) What factors contribute to the choices of mode of cooperation on both sides?

\subsection{Assumptions of the Game}

A start-up is founded based on a good business plan, but requires a large amount of capital investment to support it, and to allow enterprises to pass the growth, maturity smoothly. A certain venture investor selects the start-up via a thorough study on a large number of entrepreneurial business plans, and then enters the negotiation phase to discuss the cooperation style and profit distribution issues with the start-up. Assuming that the venture investor pours venture capital $V$ into the start-up, and if the project succeeds the profits is $C(C>V)$.

Start-up and venture investor are conducting a two-stage cooperation process as follows. On the first stage, start-up moves first. If it chooses to start business by obtaining bank loans or borrowing money from other private channels, the game ends. If it applies investment requests from venture investor to seek for cooperation, the game goes to its second phase. Then there are two choices for venture investor to select, receiving requests of cooperation or not. If the investor does not accept, the game is over; if he accepts, the venture investor and entrepreneurial company will consult with each other on the cooperation type and some details, for instance, a trade sale consultation in nonproperty cooperation or profit-sharing ratio in property cooperation. Then the game ends.

Our model implies the following assumptions:

Assumption 1: In non-property cooperation, venture investor only invests funds $V$; in property cooperation, in addition to funding $V$, there are additional value-added in- 
puts $\Delta V$; After the success of entrepreneurial project, the profits are estimated as $C$, which is common sense;

Assumption 2: The benefits in non-property cooperation are considered as a package deal, assuming that the discounted price is $P$, which means that if the start-up succeed, the venture investor can earn $P$ by selling the program or transfer the equity to others;

Assumption 3: During the whole cooperative game, moral hazard does not exist.

\subsection{Game Model and Solution}

Assume that the success rate of which start-up can resolve the financial issues to build up its operations through its own channels is $p_{1} \in(0,1)$. So when the enterprise chooses self-employment strategy, the expected profit for start-up is $p_{1} C$ and venture investor's profit is 0 . The payoff vector can be $\left(p_{1} C, 0\right)$.

When the start-up comes to a non-property investment agreement with investor, assume the success probability of start-up is $p_{2} \in(0,1)$. Also, there is $p_{2}>p_{1}$, due to their share of risk. In this stage, the expected revenue for start-up is $p_{2} C-P$, and for investor it is $P-V$. Obviously, the strategic portfolio is (non-property cooperation, accept), and responding payment vector is $\left(p_{2} C-P, P-V\right)$, in which we assume that $p_{2} C-P>0, P-V>0$. Then we can get $p_{2} C>P>V$. Otherwise, when the strategic portfolio is (non-property cooperation, refuse), the payment vector $\left(p_{1} C, 0\right)$.

When both sides draw a conclusion that they are likely to cooperate together by means of property cooperation, we assume that the success rate is $p_{3} \in(0,1)$. Because property collaboration style not only brings the start-up money, but also management experiences, supply chain resources, human relationship advantages and so forth, there exists $p_{3}>p_{2}$. Besides, they make it a deal to share profits, in which the share ratio for start-up is $r \in(0,1)$ and for investor it is $1-r$. Therefore, once the project is finished profitably, the start-up can reap $r p_{3} C$ and investor can get $(1-r) p_{3} C-V-\Delta V$. Apparently, when the strategic portfolio is (property cooperation, accept), the payoff structure is $\left(r p_{3} C,(1-r) p_{3} C-V-\Delta V\right)$. When the strategic portfolio is (property cooperation, refuse), the payoff structure is $\left(p_{1} C, 0\right)$ and there is $(1-r) p_{3} C-V-\Delta V>0$.

To sum up, start-up-investor dynamic game in extensive form is shown in Figure 1.

No matter which cooperation style the start-up and investor are likely to choose, non-property cooperation or property cooperation, both sides need to negotiate and decide the final trade price and profit-sharing ratio, which is actually a bargain. Consequently, we use the Nash bargaining solution to solve the problem (Zhang, 2012). When the start-up makes a non-property cooperation request, they will negotiate a package deal price $P$. If venture investor is willing to accept the deal, the payoff for the start-up is $p_{2} C-P$, venture investor will get a payoff, $P-V$. However, if venture investor refuse the request, the payoff for the start-up is $p_{1} C$, venture investor can get nothing.

Assuming $Z=\left(p_{2} C-P-p_{1} C\right)(P-V)$, then the optimal Nash bargaining solution should satisfy as follows: $\operatorname{Max}_{P} Z=\left[\left(p_{2}-p_{1}\right) C-P\right](P-V)$ 


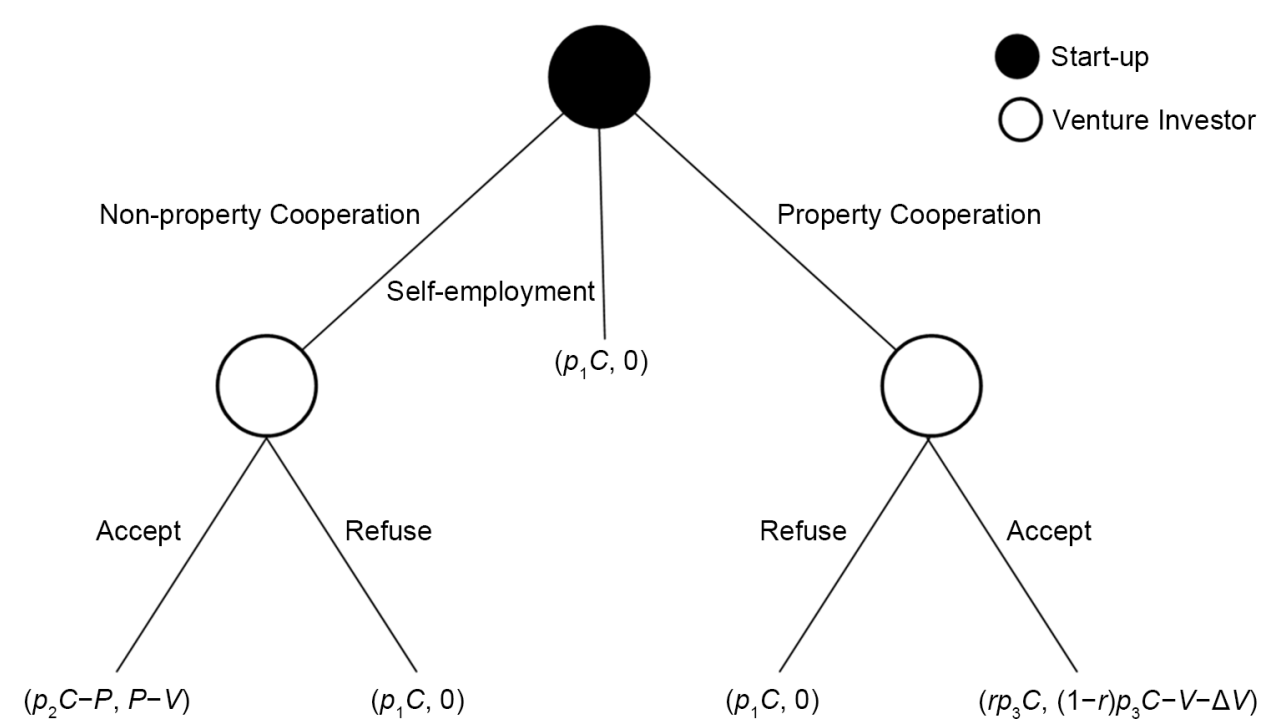

Figure 1. Two-person dynamic game of start-up and venture investor in extensive form.

Solve the first order condition of the formula, we can get

$$
\begin{gathered}
Z_{p}^{\prime}=\left(p_{2}-p_{1}\right) C-P-(P-V)=0 \\
P=\frac{\left(p_{2}-p_{1}\right) C+V}{2} .
\end{gathered}
$$

In the property cooperation, negotiated profit sharing ratio is $r$. If venture investor accepts, his payoff will be $(1-r) p_{3} C-V-\Delta V$, and for start-up it is $r p_{3} C$. If venture investor refuses to invest, his payoff is 0 and the payoff of start-up is $p_{1} C$.

Assuming $W=\left(r p_{3} C-p_{1} C\right)\left[(1-r) p_{3} C-V-\Delta V\right]$, then the optimal Nash bargaining solution should satisfy as follows:

$$
\operatorname{Max}_{r} W=\left(r p_{3}-p_{1}\right)\left[(1-r) p_{3} C-V-\Delta V\right] C
$$

Solve the first order condition of the formula, we can get

$$
\begin{gathered}
W_{r}^{\prime}=p_{3} C\left[p_{1} C-r p_{3} C+(1-r) p_{3} C-V-\Delta V\right]=0 \\
r=\frac{\left(p_{1}+p_{3}\right) C-V-\Delta V}{2 p_{3} C} .
\end{gathered}
$$

We get the mathematical expression of package price $P$ and profit ratio $r$ in Equation (1) and Equation (2). So the payoff vector can be represented as:

Self-employment (Non-property Cooperation, Refuse, Property Cooperation, Refuse):

$$
\left(p_{1} C, 0\right) \text {; }
$$

(Non-property Cooperation, Accept):

$$
\left[\frac{\left(p_{1}+p_{2}\right) C-V}{2}, \frac{\left(p_{2}-p_{1}\right) C-V}{2}\right] ;
$$

(Property Cooperation, Accept): 


$$
\left[\frac{\left(p_{1}+p_{3}\right) C-V-\Delta V}{2}, \frac{\left(p_{3}-p_{1}\right) C-V-\Delta V}{2}\right] .
$$

\subsection{Game Analysis}

We can get from the game process between the start-up and the investor that the Nash equilibrium is: $P=\left[\left(p_{2}-p_{1}\right) C+V\right] / 2, \quad r=\left[\left(p_{1}+p_{3}\right) C-V-\Delta V\right] / 2 p_{3} C$. Due to $p_{2} C>P>V$, take Equation (1) into it. We can get $p_{2} C>\left[\left(p_{2}-p_{1}\right) C+V\right] / 2>V$, then there exists $p_{2}-p_{1}>V / C$. So we can get the analysis as follows:

1) For start-ups, there is $\left[\left(p_{1}+p_{2}\right) C-V\right] / 2-p_{1} C=\left[\left(p_{2}-p_{1}\right) C-V\right] / 2>0$, because of $p_{2}-p_{1}>V / C$. We can know from the inequality that $\left[\left(p_{1}+p_{2}\right) C-V\right] / 2>p_{1} C$. Therefore, compared to the non-property cooperation, self-employment is a dominated strategy. In addition, when the start-up brings up with non-property cooperation strategy, refusing is a bad strategy for venture investor.

2) When $p_{3}-p_{1}>(V+\Delta V) / C$, there are $\left[\left(p_{1}+p_{3}\right) C-V-\Delta V\right] / 2>p_{1} C$ and $\left[\left(p_{3}-p_{1}\right) C-V-\Delta V\right] / 2>0$. For start-up self-employment is a bad strategy and in property cooperation accepting is the best choice for venture investor.

3) When $p_{3}-p_{2}>\Delta V / C$, there are $\left[\left(p_{1}+p_{3}\right) C-V-\Delta V\right] / 2>\left[\left(p_{1}+p_{2}\right) C-V\right] / 2$ and $\left[\left(p_{3}-p_{1}\right) C-V-\Delta V\right] / 2>\left[\left(p_{2}-p_{1}\right) C-V\right] / 2$. (Property Cooperation, Accept) is the strictly dominant strategy combinations for both start-up and venture investor and vice versa. Consequently, when $p_{3}-p_{2}>\Delta V / C$, the Nash solution is (Property Cooperation, Accept); when $p_{3}-p_{2}<\Delta V / C$, the Nash bargaining solution is (Non-property Cooperation, Accept). Additionally, in $p_{3}-p_{2}<\Delta V / C$, when other variables remain unchanged, the higher the $\Delta V$ is, the more likely the venture investor is to accept non-property cooperation.

4) Due to $r=\left[\left(p_{1}+p_{3}\right) C-V-\Delta V\right] / 2 p_{3} C$, there is $\partial r / \partial \Delta V<0$, so the higher the $\Delta V$ is, the lower the bargaining ability of start-up is in the profit share negotiation process, in which start-up may choose the non-property cooperation. Due to $P=\left[\left(p_{2}-p_{1}\right) C+V\right] / 2$, there is $\partial P / \partial C>0$. So when other variables remain unchanged, the higher the $C$ is, both sides will choose the property one.

To sum up, from the analysis above we can know that the selection of the cooperation style is influenced by fund $V$, additional inputs $\Delta V$ and the estimated profit $C$. About the selection of cooperation style, for start-ups, as long as there is a glimpse of hope to collaborate, it would never choose self-employment strategy. And if $\Delta V$ is high enough, start-up and investor will choose non-property cooperation. In contrast, when $C$ is high enough, both sides will be inclined to property cooperation.

\section{Conclusions and Limitations}

\subsection{Conclusions}

By introducing the property and non-property cooperation into the game model, it is from a new perspective to study the relationship between start-up and venture capitalist theoretically, which is more simple and effective for both sides to lower the risk and uncertainty to some degree. Also the results acquired from the solution of the game can 
offer some guidelines for start-ups and investors in practice. Firstly, as for the factors influencing the cooperation, start-up and venture investor can take the amount of funding, extra investment, entrepreneurial success estimated value etc. into consideration when deciding to choose the cooperation style.

Secondly, in order to reduce business risks and run its operations, start-ups always try to seek the possibility of cooperation with venture investors, instead of starting a business independently. Results of game analysis also show that cooperation is the best choice for both sides. When the program needs extremely high additional investment from investors, the start-ups should choose the non-property cooperation, because in that condition start-ups' bargaining ability is weaker than investors, which is not good for the start-ups. Nowadays, many start-ups own super innovative ideas and business vision and can raise venture fund successfully. If they choose the property cooperation style, once the investors pour billions of funds into the start-up, thus becoming the controlling shareholder, the start-up may not keep moving on the original direction. That is the conflicts about the management, strategy even the vision of the company between start-ups and venture investors. Therefore, thinking the cooperation style before cooperating with each other is efficient for both sides.

Thirdly, when the entrepreneurial item is more likely to obtain higher profits, venture investors had better to choose property cooperation. Because venture investors' additional value-added investment is the key for start-ups to grow, thus the more valuable the project is, the more necessary it needs venture investors' extra assistance such as experience in business management despite the necessary fund. At the same time, the venture investor can reap great profits share from property cooperation.

\subsection{Limitations}

Although this model explains the cooperative game between start-up and venture investor in selection and negotiation stages by introducing property cooperation and non-property cooperation, there is only one start-up and one venture investor as participants, which is relatively simple and the package trade price in non-property cooperation is also simplified. Thus more participants can be added to game model to explain more complex situation between start-up and venture investor in future researches. Besides, the model can increase the number of variables, such as the entrepreneurship ability of entrepreneurs, the trust relationship between them and so on which influence the choice of both sides about how to cooperate in order to provide more effective advices for start-ups and investors.

\section{References}

Cai, D., Chen, Z. L., \& Liu, X. P. (2015). Impacts of Venture Capital on Chinese Entrepreneurial Firms' R\&D Activities. R\&D Management, 27, 1-11.

Dong, J., Zhai, H. Y., \& Wang, J. P. (2014). Management Patterns of Venture Capital Institutes to Start-Ups: From the Perspective of Industrial Expertise and Uncertainty. Foreign Economics \& Management, 36, 1-11. 
Huang, H., \& Wang, X. F. (1998). The Operation Mode of Venture Capital. Investment and Construction of China, 11, 40-42.

Jiang, W., \& Li, R. (2014). An Analysis of the Game of the Venture Investment and Start-Up. Enterprise Financial Forum, 9, 35-40.

Kaplan, S., \& Stromberg, P. (2001) Venture Capitalists as Principals: Contracting, Screening and Monitoring. American Economic Review, 91, 426-430. http://dx.doi.org/10.1257/aer.91.2.426

Li, W. (2012). The Analysis of Game Theory about the Cooperative Mechanism between Entrepreneurial Enterprise and Venture Capital. Science \& Technology Progress and Policy, 7, 98101.

Luo, W., \& Tang, Y. H. (2001). How to Choose the Organizational Mode of Cooperative Innovation. Studies in Science of Science, 4, 103-106.

Ma, H. D., \& Yuan, C. H. (2010). Evolutionary Game Analysis of Venture Enterprise and Venture Capital Adverse Selection. Productivity Research, 5, 220-223.

Mai, Y. Y., Li, J. T., \& Xiong, C. (2012) The Impact of Venture Capital and Angel Investment on Innovative Activity of Venture Enterprises. $R \& D$ Management, 24, 79-84.

Tu, Z. R. (2005). An Analysis on Playing Game between Venture Enterprise and Venture Capital. Finance Economics, 3, 127-132.

Xiao, J., Tan, S., \& Yuan, J. G. (2008). Evaluation Model of Venture Investment Projects of Technological Company. Finance \& Economics, 244, 79-85.

Wu, J. L., Bai, Z. C., \& Zhou, X. H. (2011) Innovation of Start-Ups and Venture Capital Exits. Science of Science and Management of S. \& T, 2, 58-63.

Zhang, W. Y. (2012). Game Theory and Information Economics. Shanghai: Shanghai People's Publishing House.

\section{Submit or recommend next manuscript to SCIRP and we will provide best service for you:}

Accepting pre-submission inquiries through Email, Facebook, LinkedIn, Twitter, etc.

A wide selection of journals (inclusive of 9 subjects, more than 200 journals)

Providing 24-hour high-quality service

User-friendly online submission system

Fair and swift peer-review system

Efficient typesetting and proofreading procedure

Display of the result of downloads and visits, as well as the number of cited articles

Maximum dissemination of your research work

Submit your manuscript at: http://papersubmission.scirp.org/ 